\section{Psykologiske forsvarsmekanismer på en forståelig måte}

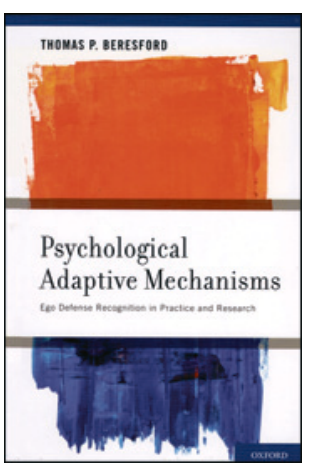

Thomas P. Beresford

Psychological adaptive mechanisms

Ego defense recognition in practice and research. 319 s, tab, ill. Oxford: Oxford University Press, 2012. Pris GBP 40 ISBN 978-0-19-979449-2

Forfatteren er professor i psykiatri ved University of Colorado. Han har tatt utgangspunkt i forelesninger for medisinstudenter og leger i spesialisering i psykiatri i denne pedagogiske og illustrative boken om psykologiske forsvarsmekanismer. Det var Sigmund Freuds (1856-1939) datter Anna Freud (1895-1982) som først og best beskrev hvordan egoet bruker forskjellige forsvarsmekanismer som respons på stress - for å unngå angst.

Denne boken bygger først og fremst på psykiateren George Vaillants (f. 1934) inndeling av forsvarsmekanismene i følgende fire domener: primitive, umodne, nevrotiske og modne. Boken er en påminnelse om at også amerikanske psykiatere i sin forståelse og behandling ofte bruker psykodynamisk tenkning.

Et ganske interessant forord gir noe av bakgrunnen, både teoretisk og praktisk. Deretter kommer et kapittel om menneskets tilpasning, fulgt av to viktige kapitler kalt The Clinical Model og The Clinical Method. I det første presenterer forfatteren Vaillants forsvarsmekanismer og en illustrasjon av hvordan stress påvirker egoet, og hvordan dette kan føre til angst. I det andre beskriver forfatteren en trinnvis algoritme i form av et enkelt flytdiagram som viser veien til aktuelle domener av forsvarsmekanismer. Kapittel 4 til 21 omhandler de enkelte forsvarsmekanismene under hvert domene, fra primitive til modne. Boken avsluttes med et kapittel om praktisk og klinisk bruk av denne kunnskapen, f.eks. ved psykiatrisk diagnostikk. Kapitlene som omhandler de enkelte forsvarsmekanismene, er pedagogisk og konsistent oppbygd. Det er eksempler fra klassisk og kjent litteratur (Homer, Shakespeare, Dickens, Dostojevskij etc.), men også eksempler fra dagligliv/ familieliv, psykiatriske vignetter og også i hvert kapittel hvordan en «intern» eller turnuslege reagerer med forskjellige forsvarsmekanismer på arbeidsstress. Gjennomgående brukes flytdiagrammet for å «diagnostisere» hvilken type forsvar personene bruker i de enkelte eksemplene.

Boken har også et utviklingspsykologisk perspektiv. Beresford gir eksempler fra barndom og ungdom som viser at flere av de mer primitive og umodne forsvarsmekanismene i tidlige år, er ganske så normale, f.eks. toåringen som nekter for å ha gjort i bleien. Medisinstudenter får nok altfor lite undervisning i normal psykologi, til forskjell fra f.eks. normal anatomi og fysiologi. Hvordan skal man vite hva som er sykelig, hvis man ikke vet hva som er normalt? Denne boken er et bidrag i så måte.

Den nyanserte fremstillingen og de tallrike eksemplene fra litteratur og dagligliv er både en svakhet og en styrke. Det gjør teksten tidkrevende å lese, og vignettene kunne nok med fordel ha vært færre. Men for den litteraturinteresserte leseren med sans for eksempler på dypere psykologisk innsikt hos kjente forfattere og diktere, er boken en liten skattkiste.

\section{Grundig om nevropsykologisk rehabilitering etter traumatisk hjerneskade}

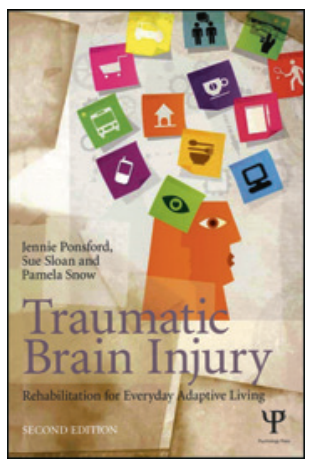

Jennie Ponsford, Sue Sloan, Pamela Snow Traumatic brain injury

Rehabilitation for everyday adaptive living. 2. utg. 414 s, tab, ill. Hove: Psychology Press, 2012. Pris GBP 40

ISBN 978-1-84872-027-5

Jennie Ponsford og medarbeidere er alle psykologer med imponerende erfaring og vitenskapelig produksjon av artikler om psykologiske senfølger etter traumatisk hjerneskade. Boken er et resultat av forfatternes egne erfaringer, støttet av tilgjengelig, vitenskapelig litteratur. Gjennomgåtte referanser er listet opp på de siste 65 sidene, og leseren får en grundig oversikt over relevante publikasjoner.

Det er ti kapitler. I de to første kapitlene tar forfatterne for seg nyttige aspekter ved vurdering av traumatisk hjerneskade - både i akuttfasen og i rehabiliteringsprosessen. Disse kapitlene er meget leseverdige for alle yrkesgrupper som jobber med pasienter med traumatiske hjerneskade.

Styrken ved denne teksten er beskrivelsen av de skalaene man bruker for å evaluere hjerneskade i akuttfasen og i senere rehabilitering. I tillegg har forfatterne laget punktvise lister og skjemaer for hovedprinsippene i vurdering og rehabilitering av pasienter. Disse er nyttige som huskelister for dem som jobber med liknende problemstillinger. De har også satt av tilstrekkelig plass til vurdering av prognosen - et emne som alltid er en utfordring for de involverte spesialistene. I de andre kapitlene retter forfatterne først og fremst søkelyset mot rehabilitering av kognitive konsekvenser og forandringer $i$ atferd etter hjerneskade.

I alle kapitlene vier forfatterne mye oppmerksomhet til familiens behov for informasjon og deres deltakelse i rehabiliteringsprosessen. Forskjellige problemstillinger er illustrert med kasuistikker. Dette er nyttig for å forstå den praktiske gjennomføringen av nevropsykologisk rehabilitering. Noen kasuistikker er gjentatt flere ganger forskjellige steder, avhengig av klinisk problemstilling. Det kunne vært nyttig med en kort rekapitulering av sykehistorien i alle kapitlene - istedenfor henvisning til tidligere beskrivelser av skadetilfellet. Delen som handler om barn med traumatisk hjerneskade, er grundig og oversiktlig.

Forfatterne mener selv at boken først og fremst er nyttig for psykologer som jobber med rehabilitering av pasienter med hjerneskade. Etter min mening appellerer enkelte deler utvilsomt bredere. For både leger og andre faggrupper som deltar i rehabiliteringsprosessen, kan de være en nyttig kilde for oppdatering om evaluering og rehabilitering av pasienter med hjerneskade.

\section{Tiina Rekand}

Nevrologisk avdeling

Haukeland universitetssykehus 